Environment Conservation Journal 15(3)35-40, 2014

ISSN 0972-3099 (Print) 2278-5124 (Online)

Abstracted and Indexed

\title{
Incidences of winter fish kill in subtropical Surinsar Lake (Ramsar Site) in Shivalik hills of Jammu (J\&K)
}

\author{
S.P.S. Dutta $\bowtie$, D. Slathia and Chandbala
}

Received:24.08.2014

Accepted: 28.10.2014

\begin{abstract}
Mass mortality of fish was observed in the morning on 02-02-2011 in winter monomictic Surinsar lake, Jammu and has been reported. Maximum count of dead fish was shared by Puntius spp. (P. ticto, $P$. conchonius and $P$. sophore). Other dead fishes of family Cyprinidae include Rasbora rasbora, Esomus danrica and Cyprinus carpio communis. A few dead specimens of air breathing Heteropneustes fossilis and Channa punctatus were also seen. In the present paper, possible causes of fish kill have been described.
\end{abstract}

Keywords: Ramsar site, Surinsar Lake, water quality, winter fish kill, winter monomictic

\section{Introduction}

Fish mortality in lotic and lentic inland waterbodies has earlier been reported by (Ganapati and Alikunhi, 1950; Ganapati and Chacko, 1951; Banerjea et al. 1956; Banerjea and Motwani, 1960; Khan and Hussain, 1976; Hingorani et al., 1977; Bhagat et al., 1979; Malhotra et al., 1979; Sharma et al., 1985; Rao et al., 1989-1990; Wanganeo et al., 1994; Dutta et al., 1997; Down to Earth, 2002; Hurst, 2007 and Ruuhijarvi et al., 2010). Winter fish kill involving carps and air breathing fishes from non-polluted subtropical Surinsar lake has been described and is of serious concern. Earlier, Malhotra et al. (1979) noticed mortality of Puntius species from this lake.

\section{Material and Methods}

\section{Study area}

Lake Surinsar $\left(75^{\circ} 02^{\prime} 3^{\prime \prime} \mathrm{E}\right.$ and $\left.32^{\circ} 46^{\prime} 30^{\prime \prime} \mathrm{N}\right)$, an important subtropical Shivalik lake about $25 \mathrm{~km}$ to the north east of Jammu city, is situated at an elevation of $606 \mathrm{~m}$ above mean sea level (Fig. 1). It is oval in contour with a sharp notch towards northwest. The circumference of the lake is $2.469 \mathrm{~km}$. Maximum depth of lake is $24.05 \mathrm{~m}$. Main source of water in lake is rain and runoff from catchment. The lake is the main source of drinking water to the inhabitants in the vicinity.

\section{Author's Address}

Department of Environmental Sciences University of Jammu, Jammu

E-mail:duttasps@gmail.com

\section{Methodology}

Water samples for physicochemical analysis were collected from the surface near the site of fish kill in plastic containers and analyzed on spot by standard methods (16). Air and water temperature were recorded by mercury bulb $\left({ }^{0} \mathrm{C}\right)$ thermometer and transparency by Secchi disc. Dead fishes were collected for detailed study in the laboratory.

\section{Results and Discussion}

Dead floating fishes in thousands were seen near the water pumping station of lake Surinsar in the morning on 02-02-2011 (Fig. 2\&3). A few dead specimens of Cyprinus carpiocommunis were, however, seen scattered all over the lake in the area of agricultural fields (Fig 4), near the temple site (Fig. 5), market side (Fig. 6) and in open water (Fig. 7). Analysis of dead specimens has shown the mortality of fishes belonging to order Cypriniformes (Puntius ticto, Puntius conchonius, Puntius sophore, Rasbora rasbora, Esomus danrica and Cyprinus carpio communis), Siluriformes (Heteropneustes fossils) and Ophiocephaliformes (Channa punctatus). Among dead fishes, maximum percentage was shared by Puntius species belonging to Cypriniformes. The weight of dead specimens of Cyprinus carpiocommunis varied between 250-500 g. Among air breathing fishes, only a few dead specimens of Heteropneustes fossilis and Channa punctatus were observed (Fig.5). 


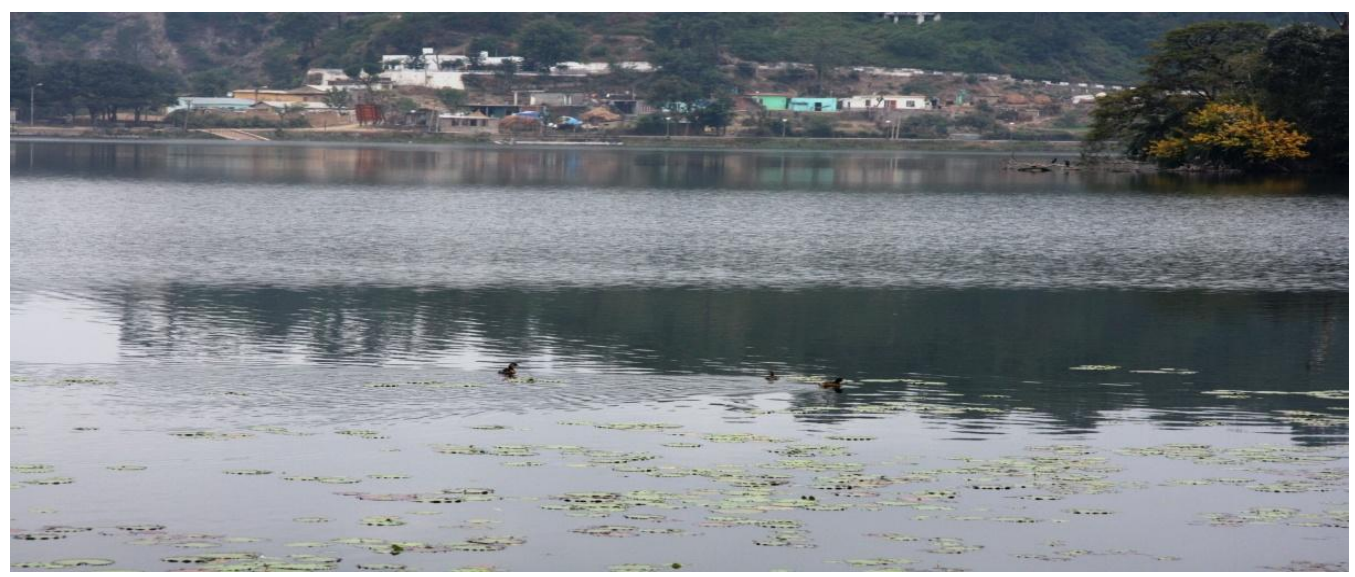

Fig.1 Panoramic view of Surinsar lake, Jammu.
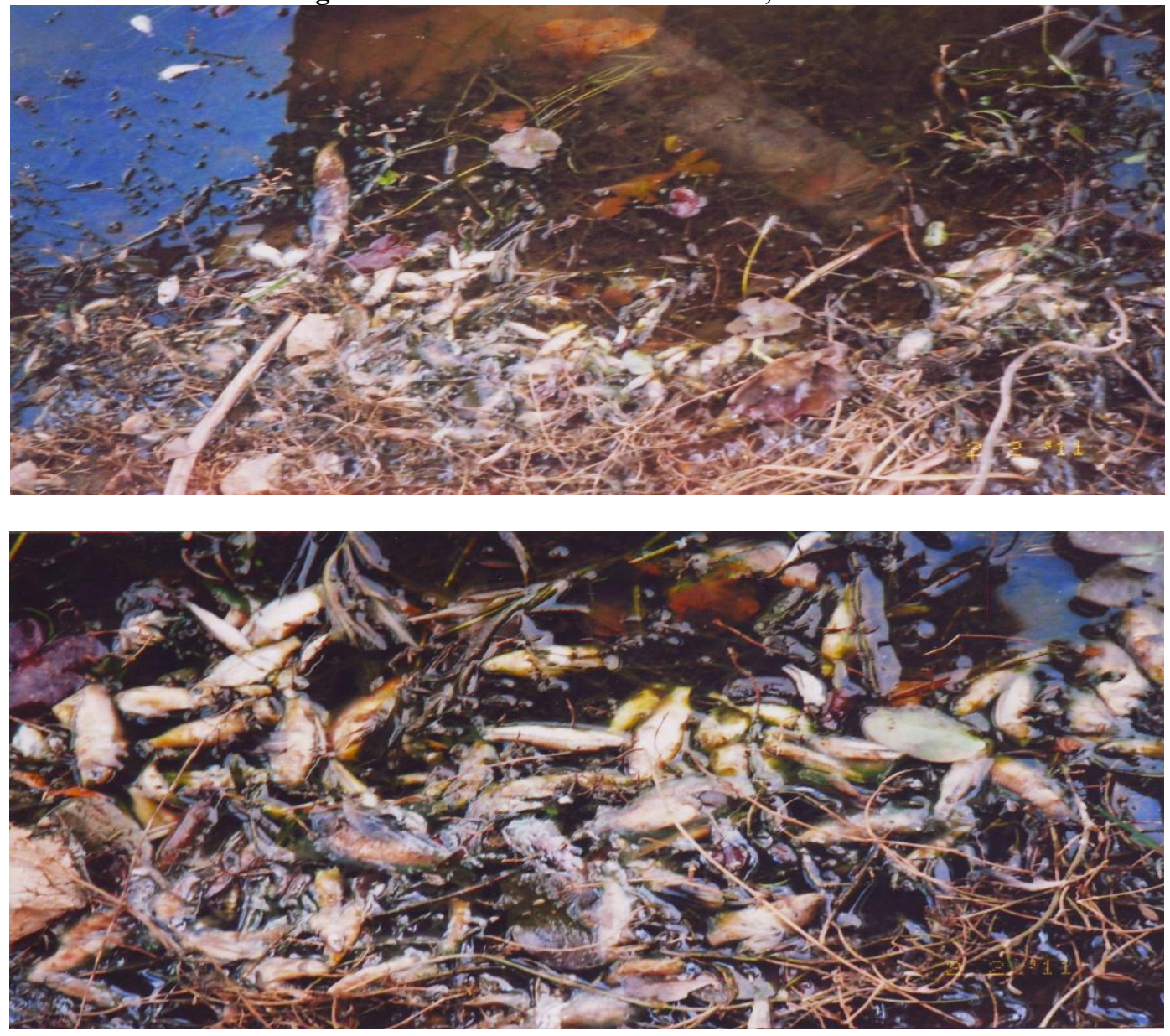

Fig. 2 and 3 : Mass mortality of fishes near pumping station 
Incidences of winter fish kill in subtropical Surinsar Lake

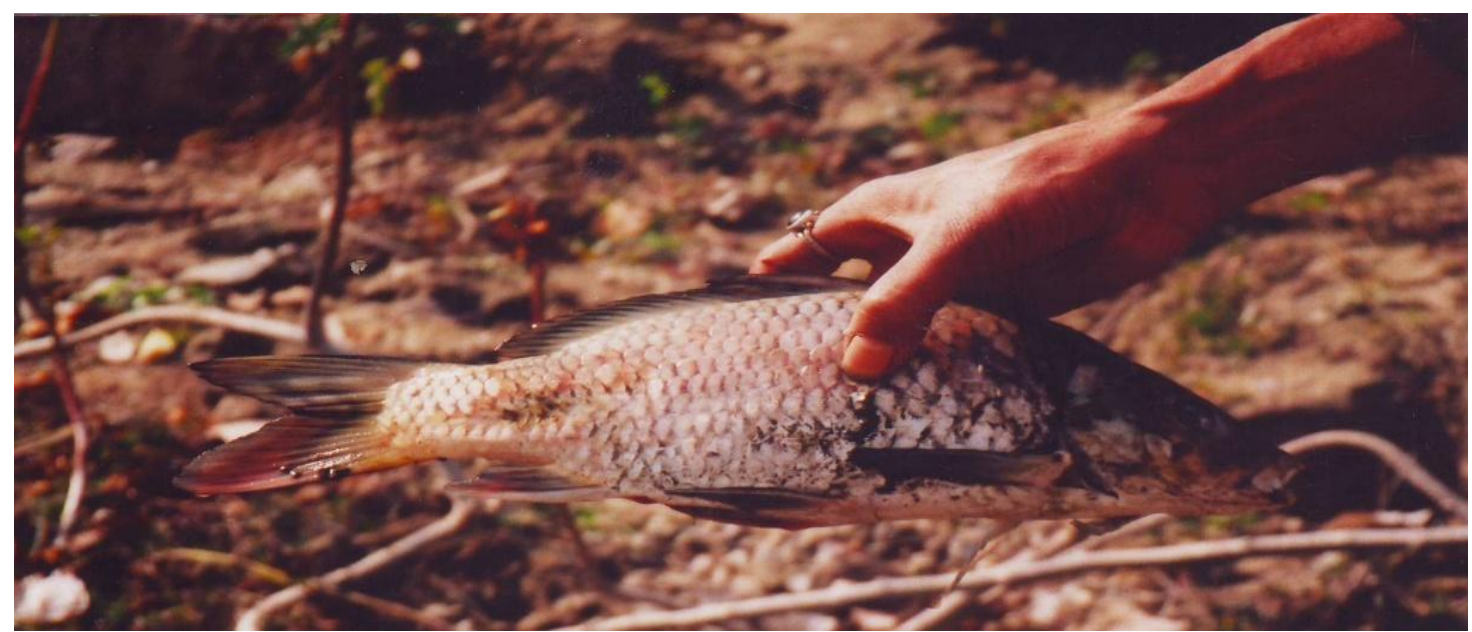

Fig. 4 Dead specimen of Cyprinus carpio near agricultural fields

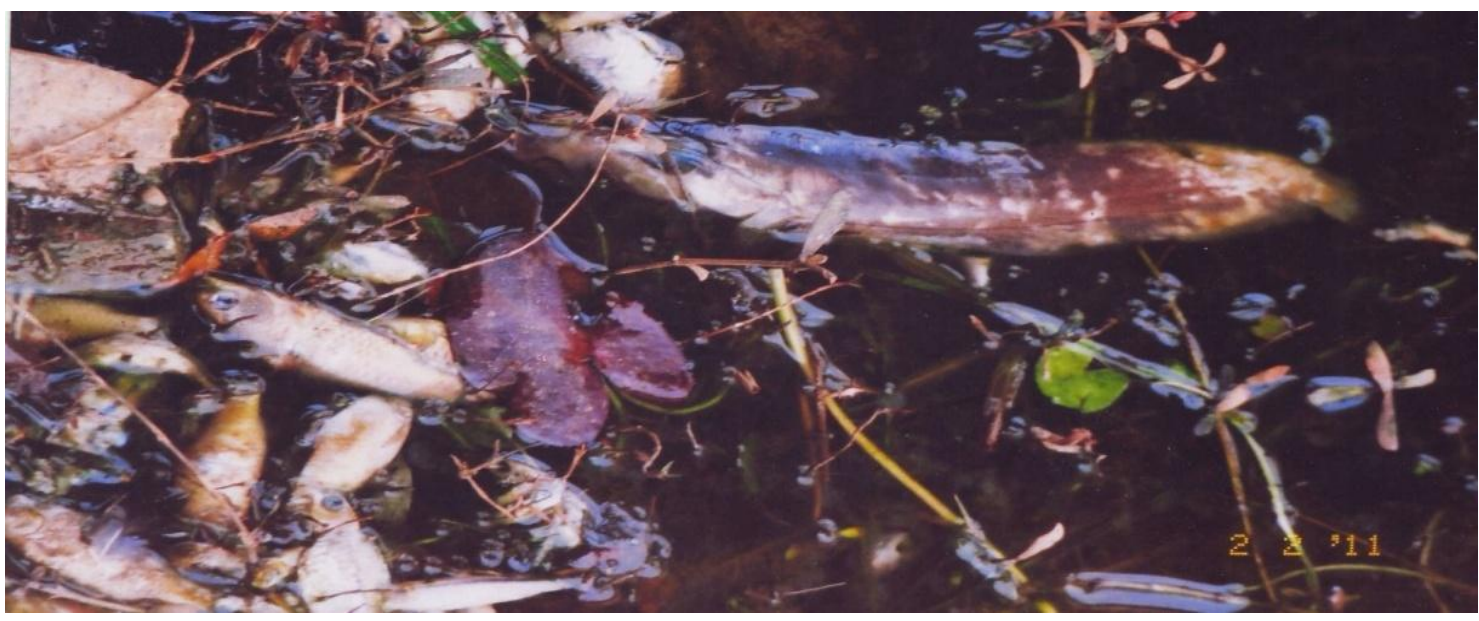

Fig. 5 Dead specimen of Heteropneustesfossilisnear temple site

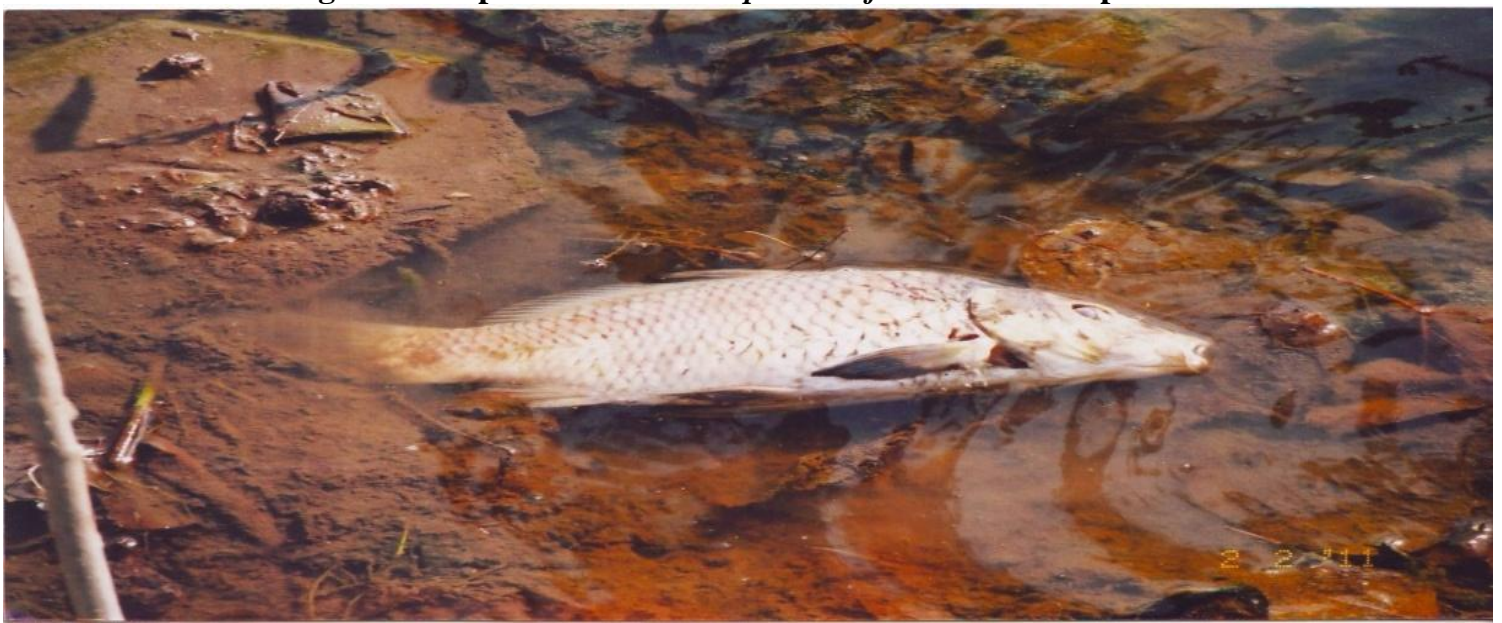

Fig. 6 Dead specimen of Cyprinuscarpio near market site 


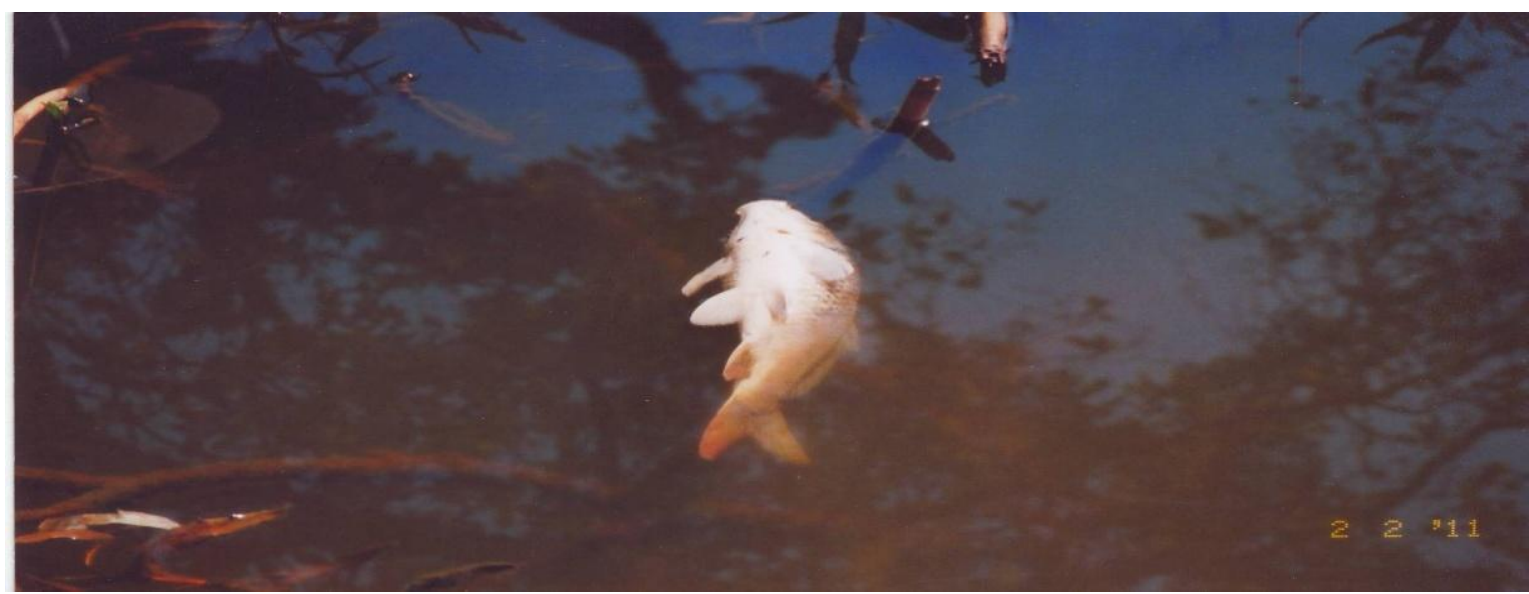

Fig. 7: Floating dead specimen of Cyprinuscarpio

At the time of this observation, live fish specimens were also seen swimming in large number among the dead specimens. This indicates that fish kill was spontaneous in the area and water quality was normal in the morning. Visual observations have revealed that apparently there was nothing wrong with these dead fishes. Microscopic examination of skin and gills of dead fish specimens revealed absence of any ecto-parasite. However, some dead specimens were covered with fungus. Surface water analysis at the site of dead fishes revealed optimum water conditions(air temperature $19.5^{\circ} \mathrm{C}$, water temperature $16.3^{\circ} \mathrm{C}$, depth $72 \mathrm{~cm}$, transparency $9.0 \mathrm{~cm}$, salinity $0.3 \mathrm{ppt}$, electrical conductivity $0.150 \mathrm{mS} / \mathrm{cm}$, total dissolved solids $105.18 \mathrm{ppm}$, $\mathrm{pH}$ 7.6, bicarbonate $171.17 \mathrm{mg} / \mathrm{l}$, chloride 11.84 $\mathrm{mg} / \mathrm{l}$, calcium $35.07 \mathrm{mg} / \mathrm{l}$, magnesium $5.71 \mathrm{mg} / \mathrm{l}$, sodium $16.7 \mathrm{mg} / \mathrm{l}$, potassium $3.5 \mathrm{mg} / \mathrm{l}$, phosphate $0.145 \mathrm{mg} / \mathrm{l}$, nitrate $0.358 \mathrm{mg} / \mathrm{l}$ and sulphate 2.33 $\mathrm{mg} / \mathrm{l})$ except low DO $(3.10 \mathrm{mg} / \mathrm{l})$ and high free $\mathrm{CO}_{2}$ $(20.5 \mathrm{mg} / \mathrm{l})$ which may be a cause of winter kill in the Surinsar lake. Earlier workers attributed fish morality to various factors such as oxygen depletion (Ganapati and Alikunhi, 1950; Banerjea et al., 1956, Hingorani et al., 1977; Sanzi, 1981; Ruparelia et al. 1986 and Ruuhijarvi et al. 2010), rise in free $\mathrm{CO}_{2}$ (Malhotra et al. 1979 and Powers, 1938, 1939), critically low DO and unfavourable summer high temperature (Moore, 1942), high water temperature, free $\mathrm{CO}_{2}$, alkalinity and low DO (Bhagat, et al. 1979) and combined toxic concentration of free $\mathrm{CO}_{2}$, hydrogen sulphide and acute oxygen depletion (Khan and Hussain, 1976).Welch (1951) summarized winter fish kill in some lakes in USA and ascribed it to oxygen depletion and effects of various decomposition products. Beamish and Harvey (1972) attributed fish mortalities in La cloche mountain lakes, Ontario, to acidification caused by industrial emissions. Rao et al. (1989-1990) ascribed fish kill in Hussainsagar lake due to the oxygen depletion, acute temperature, cumulative effect of sewage and industrial effluents containing various toxic substances which were choking the gills through fine deposition of pollutants, thus, affecting the respiratory activity of the fish. Wanganeo et al. ( 1994) recorded an incidence of mortality of Puntius ticto, Channa punctatus and Chandanama in lower lake of Bhopal in the early morning of $26^{\text {th }}$ and $28^{\text {th }}$ October, 1992. They assigned this mortality to toxic effects of decomposing Microcystis blooms and mixing of bottom and surface water causing oxygen decline. Dutta et al.(1997) noticed mass mortality of fishes belonging to Cypriniformes, Siluriformes and Ophiocephaliformes in Behlolnullah, Jammu and attributed it to sudden discharge of large amount of turbid industrial effluents showing oxygen absence having $\mathrm{H}_{2} \mathrm{~S}$, high free $\mathrm{CO}_{2}$ (51.74 $\mathrm{mg} / \mathrm{l}$ ) and high concentration of various anions and cations causing imbalance in abiotic characteristics of Behlolnullah. Incidence of mass mortality of fishes during summer (June 13, 2002) was observed in Yamuna river in Agra and has been discussed in Down to Earth (2002). This mortality was attributed to several factors like low DO $(1.7 \mathrm{mg} / \mathrm{l})$, discharge of polluted water from Mathura refinery, chemical poisoning, pollutants flowing with the discharged water between Sikandara and Agra water works. As the river bed is used for agriculture, including applications of manure and 
pesticides, organic load is added to the river. Organic load enrichment, coupled with increase in discharge could have caused inundation and churning of river bed, could have led to DO depletion and fish suffocation and death. This theory was not accepted by various agencies as there was mortality of some air breathing tortoises also in the area. Pandita (2005) concluded mass fish mortality in lake Surinsar in February 1997 to the winter lake overturn causing oxygen depletion $(0.5$ $\mathrm{mg} / \mathrm{l}$ ) and low $\mathrm{pH}(5.8)$. Hurst (2007) discussed various causes and consequences of winter kill in marine environment. Ruuhijarvi et al. (2010) ascribed oxygen deficit conditions causing winter mass mortality of fishes in two lakes of Finland.

\section{Conclusion}

In the present study, winter fish kill as observed on 02-02-2011, cannot be attributed to direct water pollution (absence of any industry in the area) or indirect pollution caused by acid rain. Moreover, $\mathrm{pH}$ of water in the optimum range rules out any acidification resulting from rain water. Surface water analysis at the site of fish kill indicates low DO $(3.10 \mathrm{mg} / \mathrm{l})$ and high free $\mathrm{CO}_{2}(20.5 \mathrm{mg} / \mathrm{l})$ which may be a cause of winter fish kill in the Surinsar lake. It is possible that during winter overturn deoxygenated bottom water, containing various decomposition products came to the surface and this resulted in sudden oxygen depletion and fish suffocation and death. Presence of a few dead specimens of air breathing Heteropneustes fossilis and Channa punctatus suggests that this winter fish kill cannot be attributed only to oxygen depletion and free $\mathrm{CO}_{2}$ enrichment. A detailed analysis of bottom water and sediments and diel analysis of water during winter overturn is required before concluding for a possible cause of fish death. It is pertinent to mention that no such sudden winter kill is observed in the lake after 2011 till date.

\section{Acknowledgements}

Authors gratefully acknowledge the necessary laboratory facilities provided by Head, Department of Environmental Sciences, University of Jammu, Jammu for carrying out the present work. The authors further declare that they have no conflict of interest.

\section{References}

APHA, 1998.Standard methods for examination of water and waste water $14^{\text {th }}$ ed. American Public Health Association, New York.

Banerjea, S. and Motwani, M.P. 1960. Some observations on pollution of the Suvaon stream by the effluents of a sugar factory Balrampur (U.P.).Indian J. Fish.7: 107-128.

Banerjea, S., Motwani, M.P. and Karamchandani, S.J. 1956. A case of heavy fish mortality in the River Son a Dehri on sone, Bihar caused by the wastes of the Rohtas Industries Ltd. ,Dalmianagar. Indian J. Fish3: 186-196.

Beamish, R.J. and Harvey, H.H. 1972.Acidification of the La Cloche mountain lakes, Ontario and resulting fish mortality J. Fisheries Resources Board of Canada.29 (8): 11311143 .

Bhagat, M.J., Dwivedi, S.N. and Bohra, O.P. 1979. A note on the fish mortality in Powailake, Bombay. Geobios5: 180181.

Down to Earth 2002. Fishy deaths. Mystery shrouds large-scale fish fatalities in the Yamuna, with conflicting official theories being floated. Down to Earth, July $15^{\text {th }}: 7-8$.

Dutta, S.P.S., Kaul, V., Sharma, J. and Kaur, H. 1997. An incidence of fish kill in Behlolnullah, a tributary of river Tawi, Jammu, J\&K. J. Env. Biol. 18(3):263-266.

Ganapati, S.V. and Alikunhi, K.H. 1950. Factory effluents from the Mettur dam, Madras and their pollution effects on the fisheries of the River Cauvery. Proc. Nat. Acad. Sci. , India. 16: 189-200.

Ganapati, S.V. and Chacko, P.I. 1951. An investigation of the River Godavari and the effect of paper mills pollution at Rajamoundary.Proc. Indo-Pacific Fish.Coun.3: 70-74.

Hingorani, H.G., Rao, K.M. and RaoRamachandran R. 1977. An attempt to study pollution and fish mortality in HussainSagarreservoir in Hyderabad. J. Indian Fish. Assoc. $3 \& 4$ (1\&2): 74

Hurst, T.P. 2007. Causes and consequences of winter mortality in fishes Journal of Fish Biology71(2): 315-345

Khan, M.A. and Hussain, M.A. 1976.Preliminary observations on pollution of HussainSagar Lake caused by industrial effluent Indian.J. Environ. Health.18(3): 227-232.

Malhotra, Y.R., Jyoti, M.K. and Sehgal. H. 1979. Causes of size and sex restricted kill of Puntiusconchonius in a subtrophical lake in Jammu. Ind. J. Exp. Biol. ,17 (8): 836837.

Moore, W.G. 1942. Field studies on the oxygen requirements of certain fresh water fishes. Ecology, 23:317-329. 
Dutta et al.

Pandita, R.N.2005. Survey report on fisheries resources of District Udhampur. Department of Fisheries J and K Govt. 52-60.

Powers, E.B. 1938. Factors involved in the Mortality of fishes, trans. Am. Fish. Soc. ,67: 271-281.

Powers, E.B. 1939. Chemical Factors Affecting the Migratory Movements and the pacific Salmon. In the Migration and conservation of Salmon Publ. A.A.A.S., No. 8, pp. 72-85.

Rao, K.V.R. , Pandey, A.K. and Pandey, P. 1989-1990. An instance of major fish kill (Notopterus notopterus) in HussainSagar (Lake) on $24^{\text {th }}$ April), 1990. Matsya ,15 and $16: 164: 167$

Ruparelia, S.G. ,Verma, Y., Mehta, N.S., Saiyed, S.R. and Ramprasad, T.N. 1986. An episode of massive fish mortality in Lake Kankariya- A case study and follow up surveillance.Indian J. Ecol. 13: 10-14.
Ruuhijarvi, J., Rask, M., Vesala, S., Westermark, A., Olin, M., Keskitalo, J. and Lehtovaara, A. 2010. Recovery of the fish community and changes in the lower trophic levels in a eutropic lake after winter kill of fish. Hydrobiologia 645:145-158.

Sanzi, N. 1981.Fish mortality in Bawaria in 1979. Fisher Teichwirt. 32: 136-139.

Sharma, K.P. ,Kakkar, V.K. and Pathan, S.D. 1985. Effects of Industrial effluents on fishes in Kota, Rajasthan, India.Intl. J. Acad. Icthyol. (Proc. V. AISI) 6: 141-144.

Wanganeo, A., Pani, S., Nandan, M.J. and Suresh, I.V. 1994. Incidence of fish mortality in lower lake of Bhopal Geobios 21(2):145-146

Welch, P.S. 1951. Limnology.Reprint 2010.Narendra Publishing House, delhi - 110006 (India). 